\title{
Partial Purification of Indigenous Lipase from Germinated Bambara Groundnut (VoandzeiaSubterrenea)
}

\author{
Ogueche, Nnamdi Peter ${ }^{1}$, Ikwuagwu, Emmanuel Ogbonnaya ${ }^{2}$, Onah, \\ Benjamin Emenike ${ }^{3}$ \\ ${ }^{1}$ Department of Human Biochemistry, Nnamdi Azikiwe University, Nnewi Campus. \\ ${ }^{1,2,3}$ Department of Biochemistry, University of Nigeria, Nsukka. \\ pn.ogueche@unizik.edu.ng
}

\begin{abstract}
Lipase is an enzyme that catalyzes the hydrolysis of ester bonds in substrates such as phospholipids, triglycerides and cholesteryl esters. Lipase (E.C. 3.1.1.3) was extracted from the $5^{\text {th }}$ day of germination of bambara groundnut (Voandzeia subterrenea) using 0.1M phosphate buffer pH 7.8. The enzyme was purified using 60\% ammonium sulphate saturation via precipitation followed by dialysis and column chromatography using carboxymethyl cellulose. Lipase from germinated voandzeia subterrenea has various industrial applications hence alternative source of the enzyme is crucial especially from plant.
\end{abstract}

Keywords: Germination, plant source, lipase, and purification.

\section{INTRODUCTION}

Lipase (Triacylglycerol acylhydrolase) (E.C. 3.1.1.3) is an enzyme which catalyzes the hydrolysis of ester carboxyl bonds in acylglycerol to release free fatty acids and glycerol. It is capable of catalyzing esterification reaction at water restricted environment. Generally, lipase has a catalytic triad which consists of amino acid: serine, histidine and aspartate or glutamate residues. Lipases from microbial source can have their character influenced by its medium where it grows, while lipases from plant and animal sources are not influenced by their environment. Lipases from plant sources have specific properties, such as high affinity with triacylglycerol of the plant content. This property is not found in lipases from microbial sources (Huang et al., 2008). Lipases have been isolated from many species of plants, animals, bacteria, fungi, and yeast. It have been widely used in the food and other industrial applications and thus there is an increasing demand in discovering new lipase sources. Lipases are one of the important groups of biocatalysts used in biotechnological applications (Benjamin and Pandey, 2008). Permanaet al., (2012) found that lipase from germinated seeds; have higher activity, the highest activity being dependent on length of germination. Lipases have been found to be present in seeds rich in oils (Beissonet al., 2000). Although there have been studies on lipase from germinated seeds especially groundnut seeds. However, studies on lipase from germinated bambara groundnut are still limited and unexploited. Hence, this study is aimed at purifying the indigenous lipase of germinated bambara groundnut using olive oil as substrate.

\section{Materials AND Methods}

\subsection{Materials}

Chloroforms used was a product of May and Baker Ltd, olive oil-Arista chemicals, triethanolamine hydrochloride crystal - M \& M laboratory chemicals Ltd, Bovine Serum Albumin (BSA) - BDA England, Folin - ciocalteu-BDH England and Carboxymethyl cellulose -Sigma chemical company. Other chemicals used were of analytical grade.

\subsubsection{Collection of Plant Materials}

Bambara groundnut seeds (voandzeiasubterrenea) were bought locally from Ogige Main Market Nsukka, Enugu State, Nigeria.

\subsection{Methods}

\subsubsection{Germination of Bambara Seeds}

Bambara groundnut seeds were immersed in water and viable seeds settled at the bottom. The viable seeds were imbibed in water for $10 \mathrm{hrs}$ and aerated for $2 \mathrm{hrs}$ followed by another $10 \mathrm{hrs}$ imbibitions. At 
the end of the imbibitions, the seeds were germinated on already prepared germination beds for 7 days. The beds were watered every two days (Onyekwelu and Olawole, 2007).

\subsubsection{Extraction of Lipase}

2, 3, 4, 5, 6 and 7 days germinated seeds as well as un-imbibed seeds (day zero) were decoated and the roots removed. The seeds $(51.5 \mathrm{~g}$ each) were homogenized for 15 minutes with cold $0.1 \mathrm{M}$ phosphate buffer ( $\mathrm{pH}$ 7.8) using Philips blending machine (R2000) as described by Afiukwaet al., (2009) after washing them severally with distilled water. The homogenate was filtered using cheese cloth and the filtrate centrifuged for $10 \mathrm{mins}$ at $5000 \mathrm{~g}$. The supernatant containing the crude enzyme was collected and used as the crude extract while the pellets were discarded. Lipase activity was determined for each of the extracts as in the assay section below.

\subsubsection{Purification of Lipase}

The crude lipase $(100 \mathrm{mls})$ was precipitated with ammonium sulphate by the method of Doonan, (1996) at various ammonium suphate saturation (10, 20, $30-100 \%)$. After addition of ammonium sulphate, crude lipase $(100 \mathrm{ml})$ was precipitated for $12 \mathrm{hrs}$ and the resulting precipitate was collected by centrifugation at $5000 \mathrm{~g}$ for $30 \mathrm{mins}$ at $4^{0} \mathrm{C}$. The precipitate was dissolved in $20 \mathrm{mls}$ of $0.1 \mathrm{M}$ phosphate buffer $(\mathrm{pH}$ 7.8). The lipase activity and protein content of this solution were then determined.

Crude lipase (300mls) was then initially brought to $20 \%$ ammonium sulphate $\left.\left(\mathrm{NH}_{4}\right)_{2} \mathrm{SO}_{4}\right)$ saturation and was allowed to stand for $12 \mathrm{hrs}$ at $4^{\circ} \mathrm{C}$. This was centrifuged at $5000 \mathrm{~g}$ for $30 \mathrm{mins}$. The supernatant was made up to $60 \%$ ammonium sulphate saturation and allowed to stand for $12 \mathrm{hrs}$ at $4^{\circ} \mathrm{C}$. The precipitate was recovered by centrifugation at $5000 \mathrm{~g}$ for $30 \mathrm{mins}$. This was dissolved in $0.1 \mathrm{M}$ phosphate buffer $(\mathrm{pH} 7.8)$ to a final volume of $50 \mathrm{ml}$ and dialyzed for $12 \mathrm{hrs}$ against the same buffer.

The dialysate was applied into a gel filtration column $\left(2.5 \times 62 \mathrm{~cm}^{3}\right)$ with carboxymethylcellulose and pre-equilibrated with $0.1 \mathrm{M}$ phosphate buffer $(\mathrm{pH} 7.8)$ and the eluting buffer of $5 \mathrm{ml} / \mathrm{min}$ was collected. The protein content $(\lambda=250 \mathrm{~nm})$ and lipase activity $(440 \mathrm{~nm})$ were monitored for every fraction $(3 \mathrm{ml})$. The fractions which had the highest lipase activity were pooled and used as partially purified enzyme.

\subsubsection{Assay of Lipase Activity}

Hydrolytic activities of lipase were detected by the method of Marseno et al., (1998). Olive oil 50\% in isooctane $(5 \mathrm{ml})$ was mixed with $250 \mu$ l lipase. It was then incubated in a shaking water bath (100 strokes $/ \mathrm{min})$ at $35^{\circ} \mathrm{C}$ for $60 \mathrm{mins}$. The resulting oil layer was taken $(3 \mathrm{ml})$ and added with $0.6 \mathrm{ml}$ of pyridine $\mathrm{Cu}$-acetate ( $\mathrm{pH} 6.0$ ). After thoroughly mixing, the mixture was centrifuged at $750 \mathrm{~g}$ for $5 \mathrm{~min}$ and then read the absorbance of the oil layer at $\lambda=715 \mathrm{~nm}$. Oleic acid was used as a standard at concentration of $0,2,4,6,8$ and $10 \mathrm{mM}$. One unit of lipase activity was described as anount of the enzyme which produced $1 \mu \mathrm{mol}$ fatty acid per min under standard conditions.

\subsubsection{Protein Concentration}

Protein concentration in all enzyme extracts was determined as described by Lowry et al., (1951) with bovine serum albumin as a standard protein.

\section{RESULTS AND DISCUSSION}

\subsection{Variation of Protein and Lipase Activity with Days of Germination}

The result of this study shows that germination started 2 days after imbibitions and was completed in 7 days. The result showed a steady increase in lipase activity from day zero through day 2 to the $5^{\text {th }}$ day of germination. Maximum lipase activity was detected at the 5th day and at $\mathrm{pH} 7.8$ (table 1.0). The lipase activity started decreasing after day 5 through the $7^{\text {th }}$ day after imbibitions. This is possible because it has been found that lipase from germinated seeds has higher activity being dependent on the length of germination (Permanaet al., 2012). In a similar study it was found that germination of cocoa bean had highest lipase activity at day 3 after imbibitions (Permana, 2011). During germination lipase activity increases in the endosperm to hydrolyse the lipids present in endosperm to release free fatty acid as the germination progresses. 


\subsection{Purification of Lipase from Germinated Bambara Groundnut}

Solid ammonium sulphate was used to precipitate the crude lipase extract in various concentrations $(10 \%-100 \%)$. The higher the concentration of ammonium sulphate, the more protein precipitated. The lipase activity likewise increased as the ammonium sulphate concentration increases and became relatively constant from $60 \%$ concentration. Consequently, two steps precipitation $(20-40 \%$, meaning discarding precipitate at $20 \%$ saturation and continuing precipitation with $40 \%$ saturation) were selected for the study. The $60 \%$ ammonium sulphate saturation and protein precipitated when dialyzed removed impurities from the sample raising the specific activity to $0.21 \mathrm{U} / \mathrm{mgwith} 4.38$ purification fold.

The purification fold of the lipase increased to 115.76after applying carboxylmethyl cellulose G-200 column chromatographic technique. The overall purification scheme is summarized in table 2.0. This result agrees with that of Deepak, 2012 who reported that $60 \%$ saturation was proved to be effective for maximum specific activity of lipase from Bacillus PumilusRK 31; and that of Permana, (2011) who also reported that lipase activity increased during solid ammonium sulphate precipitation with increasing ammonium sulphateconcentration and became constant at the concentration of $60 \%$.

\section{Conclusion}

Crude lipase was extracted from germinated Bambara groundnut (Voandzeia subterrenea) and purified partially using $60 \%$ ammonium sulphate saturation, raising the enzyme specific activity to $0.21 \mathrm{U} / \mathrm{L}$ with 4.38 purification fold. The results of this research show that lipase enzyme could be sourced alternatively especially from Bambara groundnut.

\section{ACKNOWLEDGEMENTS}

The authors are grateful to the staff and management of postgraduate laboratory, Department of Biochemistry, University of Nigeria, Nsukka.

Table1. Variation of protein and lipase activity with days of germination

\begin{tabular}{|l|l|}
\hline Days & Lipase activity \\
\hline 1 & 0.0123 \\
\hline 2 & 0.134 \\
\hline 3 & 0.197 \\
\hline 4 & 0.256 \\
\hline 5 & 0.442 \\
\hline 6 & 0.315 \\
\hline 7 & 0.201 \\
\hline
\end{tabular}

Table2. Purification Table

\begin{tabular}{|l|l|l|l|l|l|}
\hline Purification step & $\begin{array}{l}\text { Total } \\
\text { volume } \\
(\mathbf{m l})\end{array}$ & $\begin{array}{l}\text { Total activity } \\
(\mathbf{u})\end{array}$ & $\begin{array}{l}\text { Total protein } \\
(\mathbf{m g})\end{array}$ & $\begin{array}{l}\text { Specific } \\
\text { activity } \\
\mathbf{u} / \mathbf{m g}\end{array}$ & $\begin{array}{l}\text { Purification } \\
\text { fold }\end{array}$ \\
\hline Crude lipase & 300 & 19.14 & 393.76 & 0.05 & 1.00 \\
\hline Ammonium sulphate precipitation & 300 & 7.25 & 34.11 & 0.21 & 4.38 \\
\hline Dialysis & 50 & 3.94 & 14.43 & 0.46 & 28.41 \\
\hline Carboxymethyl cellulose G-200 & 25 & 1.86 & 0.70 & 5.59 & 115.75 \\
\hline
\end{tabular}

\section{REFERENCES}

Huang, A.H.C., Lin, Y. and Wang,S. (2008) .Characteristic and biosynthesis of seed lipase in maize and other plant species. Journal of the American Oil Chemists society, 5: 897- 899

Permana, D.G.m., Indrati, R., Hastuti, P. and Suparmo, L. (2012) Aktivitas lipase indigenous kecambahbijikakao (Theobroma cacao L.).Agritech,32(4). In press

Benjamin, S., and Pandey.A. (2008). Candida nigosalipases:Molecular biology and versatility in biotechnology. Yeast, 14:1069-1087.

Onyekwelu, J.C and Olawole, J.F. (2007).Effect of storage methods on the germination and proximate composition of Treculiaafricanaseeds.Conference on International

Agricultural Research for development. 
Doonan, S.(1996). Bulk purification by fractional precipitation. In: Protein purification protocols. Doonan (Ed) Humana press Inc. Totowa, New Jersey.

Marseno, D.W.,Indrati, R. and Ohta, M (1998).A simplified method for determination of free fatty acids for soluble and immobilized lipase assay.Indonesian Food and Nutrition Progress, 5:79-83

Lowry, O.H., Rosebrough, N.J., Farr, A.l and Randall, R.J (1951).Protein measurement with folin phenol reagent.Journal of Biological chemistry, 193: 26-275.

Afiukwa, C.A., Ibiam,U.A, Edeogu, C.O., Nweke, F.Nand chukwu, U.E. (2009)

Determination of amylase activity of crude extract from partially germinated mango seeds (mangiferaoraphila). African Journal of Biotechnology,8(14) : 3294-3296

Permana, M.G.D.I (2011). Characteristics of purified Indigeneous lipase from germinated cocoa bean using phenyl sepharose. Asian Journal of Food Agricultural Industry, 4 (05) 274-285.

Deepak, S., Arpit,S. and Arun, K. (2012).Lipase from Bacillus pumilus RK31: Production purification and some properties. World Applied Sciences Journal,16 (7): 940 -948.

Samsumaharto, R.A .(2008). Partial characterization of lipase from cocoa beans (Theobroma cocoa L.) of clone PBC 159.Indonesian Journal of Chemistry,8(3).

Abigor, R.d, Uadia, P.O., Foglia,T.A.,Hass, M.J., Scott, k and Salvary, K. (2002). Partial and properties of lipase from germination seeds of Jatrophacurcas L.Journal of the America Oil Chemists Society,79:1123-1126.

Eze, S.O.O and Chilaka, F.C. (2010).Lipolytic activities in some species of germinating Cucubitaceae: Cucumeropsismaniinaud, colocynthis vulgaris L and Cucubitamos chataschrad . World Journal of Agricultural Science, 6(6).

Enujiugha, V.N. (2004). Lipase activity in dormant seeds of the African oil bean (Pentaclethramacrophyllabenth).Journal of food, 23:481-486.

Salih , G. and Mehment, A.A. (2012) .Purification and characterization of lipase from the liver of carp, cyprinuscarpio L.1758, Living in lake Todurge. Turkish Journal of Fisheries and Aquatic Sciences, 12:207-215.

Kashmiri, M.A Adnan, A. and Butt, B. W. (2006).Production, purification and partial characterization of lipase from Trichodermaviride. African Journal of Biotechnology, 5:878-882.

Beisson, F.,Tiss, A., Riviere, C. and Verger, R. (2000). Methods for lipase detection and assay: a critical review. Europian Journal of Lipids Science and Technology,9: 133-153. 